\title{
Place attachment in a foreign settlement
}

\author{
Ceren Boğaç* \\ Eastern Mediterranean University, Department of Architecture, Salamis Yolu, Gazimağusa, North Cyprus, Via Mersin 10, Turkey
}

\section{A R T I C L E I N F O}

\section{Article history:}

Available online xxx

\section{Keywords:}

Place attachment

Involuntary relocation

Refugees

Home

\begin{abstract}
A B S T R A C T
This paper examines issues arising from the involuntary relocation of Turkish Cypriot refugees from the southern to the northern portion of the island of Cyprus. After the ceasefire in 1974, participants in this study were relocated into homes originally built and occupied by Greek Cypriots. Using data obtained from questionnaires, semi-structured interviews and drawings, the study analyses their place attachment under the unusual circumstances of their own forced relocation coupled with their occupation of homes abandoned by residents also displaced by war and interethnic hostility. The study compares the place attachment of refugees to their children, who were born and brought up in the new community. The results of this study suggest that participants' future expectations shaped their attachment to their new homes and community, whilst their degree of attachment to their previous environments also played an important role in the attachment process. Younger generations, on the other hand, were more attached to their current environment than older generations; however they did not wish to be identified with their current environment.
\end{abstract}

(c) 2008 Elsevier Ltd. All rights reserved.

\section{Introduction}

The island of Cyprus, once a unified independent state, is currently divided into two parts according to the ethnicity of its inhabitants. Thus, the Republic of Cyprus, populated exclusively by Greek Cypriots, is located to the south of the island, and the country of Northern Cyprus, populated predominantly by Turkish Cypriots is located, to the north of the island. The division of the island is the result of the war of 1974. The internal conflicts, which started in the late 1950s, triggered the process of the fragmentation of settlements, street by street, neighborhood by neighborhood, and, in some instances, house by house, between the two ethnically and culturally diverse populations on the island. Many towns or villages in which both groups had resided became home to one group or the other, depending upon which group was in the majority there. A series of events took place in 1963, which led to the 1974 conflict, and the Turkish army's ${ }^{1}$ subsequent intervention resulted in the division of the island into the Greek South and the Turkish North (Fig. 1).

Since 20th July 1974, when the buffer zone (green line) was established, 65,000 people are estimated to have migrated from the south to the north (Necati, 1984, pp. 39-42), leaving behind all their

\footnotetext{
* Tel.: +90 5428553490.

E-mail address: ceren.bogac@emu.edu.tr

1 Turkey is one of the guarantor countries of the Republic of Cyprus, as well as Greece and the United Kingdom.
}

property, homes and most of their valuables and belonging. Most of them were given homes and properties in the north, which had been abandoned by the Greek Cypriots who had themselves migrated to the South of the island. The housing assigned to the refugees in the North was totally foreign to the new residents, and little was known about the whereabouts of former residents who had been forced to move to the South of the island.

Today, 34 years after the war, there is no longer any conflict between the cultural groups, mainly because each group lives within the borders of its own territory. It is possible that if the political problems surrounding the future of Cyprus are resolved, things may improve for both groups. When each cultural group chooses to remain in their respective territories, this does not appear to cause any particular problems for either group. The present research asks if it is really that easy: Has any consideration been given to the psychological effect on these groups and their subsequent generations?" Are there "open wounds" that continue to fester even after all this time, with little or no acknowledgement from the relevant authorities on either side? Furthermore, the research asks whether the process of place attachment to the new home is complicated by knowledge that the home belongs to and carries memories of the previous residents.

Research has shown that involuntary relocations can have dramatic psychological effects on people. Initially those members of the population who had to undergo the process of relocation experienced very difficult times when faced with leaving their homes. The present research suggests that in addition to facing an 


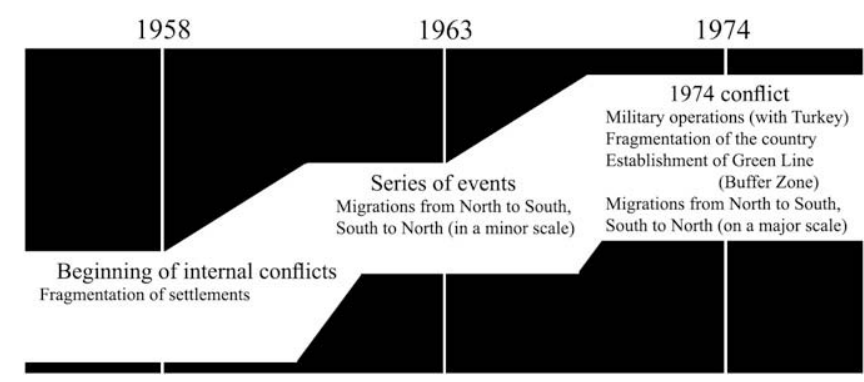

Fig. 1. Time line showing the events between 1958 and 1974.

uncertain future and the physical foreignness of their new settlement, the refugees encountered attachment problems with respect to their new environment. In the psychological literature, the effects of involuntary relocation on disruption in place attachment have been highlighted. For example, Brown and Perkins (1992), said: "After the development of secure place attachments, the loss of normal attachments creates a stressful period of disruption followed by a post-disruption phase of coping with lost attachments and creating new ones." (Brown \& Perkins, 1992, p. 279). Considerable evidence suggests that relocation and moving causes a disruption of place attachments (Anthony, 1984; Fried, 1963; Matter \& Matter, 1988). In this paper, the focus is on the psychological experience of losing one place and the process of attachment to a new place, when the new home had been involuntarily abandoned by the former residents.

The research site, which is used as a case study, is a housing

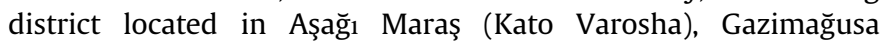

(Famagusta) city. The district was originally built by a culturally distinct people, the Greek Cypriots, former settlers of the region before 1974. Today, it hosts Turkish-Cypriot refugees from Paphos, a town located in Southern Cyprus (Fig. 2). The main question is to what degree the current occupants feel attached to the houses and surrounding locale which have been allocated to them, following the loss of their former homes and, therefore, their attachments in the south. The primary focus of the paper is on place attachment to physically foreign settlements and the effects of involuntary relocation on this process. A secondary focus is a comparison between the degree of place attachment of the refugees, who continue to carry memories of their lost attachments, with that of their children, who were born in Aşağ $\breve{1}_{1}$ Maraş after the 1974 intervention and who have no-direct relationship with Paphos town. Although Aşağ Maraş accommodated Turkish settlers from several communities, this research includes only refugees from the town of Paphos and their children.

\section{Literature review}

In contemporary literature, researchers have predominately conceptualized place bonding within environmental psychology as 'place attachment' (Altman \& Low, 1992; Giuliani, 1991; Hidalgo \& Hernández, 2001); and 'place identity' (Giuliani \& Feldman, 1993; Proshansky, Fabian, \& Kaminoff, 1983; Twigger-Ross \& Uzzell, 1996). Hernández, Hidalgo, Salazar-Laplace, and Hess (2007) claim that several authors consider 'place attachment' and 'place identity' to be the same concept and either use both terms synonymously (e.g. Brown \& Werner, 1985) or operationalize attachment in terms of identity (Stedman, 2002). Hernández et al. (2007) suggested that

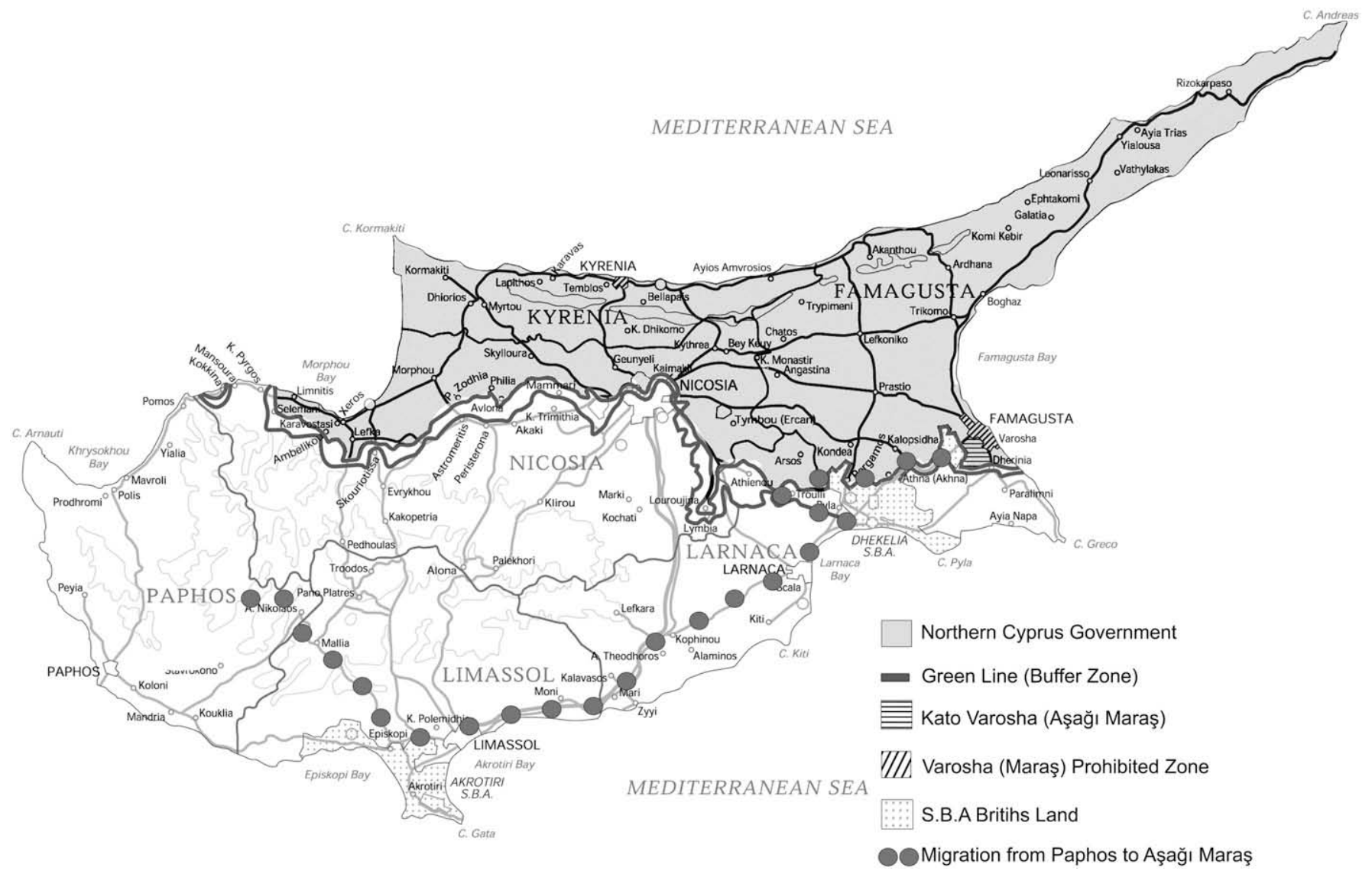

Fig. 2. Geographic map of the site. 
place attachment and place identity are two concepts that frequently overlap (Hernández et al., 2007). Twigger-Ross and Uzzell (1996), on the other hand, argue that place attachment develops and supports place identity; place identity, therefore, is more than attachment. In this paper these two key concepts (place attachment and place identity) will be used in combination to explain people-place bonds.

\subsection{Place attachment and place identity}

The term 'place attachment' is often used to refer to the bonding of people to a particular place (Altman \& Low, 1992; Giuliani, 2003... etc). Altman and Low (1992) extended their cultural explorations into the topic of 'place' and sought to discover how people 'attach' themselves to places through meaning. There are also other researchers who studied the subject within different contexts in the field of Environment Behavior, such as Brown (1987), Brown, Perkins, and Brown (2003), Giuliani (2003), Giuliani and Feldman (1993), Hidalgo and Hernández (2001), Knez (2005), Manzo (2003), Proshansky et al. (1983), and Sarbin (1983)... etc.

'Place identity' is another key concept that refers to the bonds people form with places. Proshansky et al. (1983) extended identity theory to the area of environmental psychology and proposed that 'place identity' is a "physical world socialization of the self" (p. 57). To those authors, place identity is a "potpourri of memories, conceptions, interpretations, ideas, and related feelings about specific physical settings, as well as types of settings" (Proshansky et al., 1983, p. 60). As the place attachment process grows and develops, individuals start to identify themselves with the place in question, both on a larger scale, such as with respect to nationality, city, etc. and on a smaller scale, with respect to neighborhood, homes or lodgings (Giuliani, 2003).

Attachment to place forms an important part of the character development of an individual. Place attachment, therefore, is directly connected with an individual's or a group's identity (Altman \& Low, 1992; Jörgensen \& Stedman, 2001; Knez, 2005; Proshansky et al., 1983; Stedman, 2002; Stewart, Liebert, \& Larkin, 2004; Twigger-Ross \& Uzzell, 1996). Proshansky argues; “... those dimensions of self that define the individual's personal identity in relation to the physical environment by means of a complex pattern of conscious and unconscious ideals, beliefs, preferences, feelings, values, goals, and behavioral tendencies and skills relevant to this environment" (Proshansky, 1978, p. 155).

All these statements lead us to conclude that if one loses his/her 'place', this may cause or create some confusion or disorder in one's identity. This point was stressed in research by Schward, Brenth, Philips, and Danley (1995), who quoted Eric Fromm:

"If I am what I have and what I have is lost, who then am I?" Eric Fromm (1976, p. 96)

What is emphasized here is that people put years of effort into transforming their houses into homes, which, in turn, reflect their individuality and/or identity (see Moore, 2000). Thus, it is not a difficult matter to understand the subsequent feelings experienced by a person in the event of losing her/his home environment. In the following text, the feelings of the refugees from Paphos with respect to both the houses they left behind and the houses into which they then moved, 34 years ago, are explored. In particular, this research examines place attachment processes after forced relocation into homes and a community built and designed for a culturally different group of people. As Altman and his colleagues noted, it is difficult for people to adapt to homes that do not support their cultures values and expected social processes (Altman \& Gauvain, 1981; Gauvain, Altman, \& Fahim, 1983).

\subsection{The effects of involuntary relocation on peoples' attachment to a new place}

In earlier literature, people's response to the occurrence of an environmental hazard including the devastating impact of natural forces like earthquakes, tornadoes, hurricanes, volcanoes, drought, floods... etc. have been studied by many researchers so that a better understanding of people's attachment to their homes and localities can be achieved (Erikson, 1976; Quarantelli, 1957; Raphale, 1986; Wright \& Rossi, 1981). In these studies, it is indicated that the disruption of one's sense of place through involuntary relocation, can threaten self-identity and be very overwhelming to those with strong place attachments. As stated by Brown and Perkins: "Place attachments develop slowly but can be disrupted quickly and can create a long-term phase of dealing with the loss and repairing or re-creating attachments to people and places." (Brown \& Perkins, 1992, p. 284). In many cases, people who have had to leave their damaged houses and be relocated to other parts of their country following the event of an environmental hazard, often report that they miss the mountains, oceans, or neighborhoods of their former homes, even years after they have left (Brown \& Perkins, 1992; Schward et al., 1995).

Involuntary relocations can involve injury or loss of life and possessions, losses that are integral to self-definition, which subsequently has huge negative effects on the process of attachment to the new place (Brown \& Perkins, 1992, p. 290). Milligan (1998) mentioned that people develop strong feelings, which bond them to a specific place as a result of their past experiences or memories associated with that place; sometimes the roots of this attachment go back several generations.

The present study contrasts with the existing literature because, people experienced both the involuntary relocation to a new city and then were forced to settle into the involuntarily abandoned homes of others. Here, the main question is: to what extent did the past experiences, memories and social ties of the Paphos refugees have a role to play in the attachment process to their new home and its environs?

\section{The study}

The objectives of the study are first to determine the degree to which the current occupants feel physically and socially attached both to their new 'house' and the location in which this new house is situated, after having been forced to leave their original homes. Second, these responses are compared with their children, who have always lived in Așağ 1 Maraş, and have no relationship with the birthplaces of their parents. For the objectives of the study, research participants were selected from two generations: (i) refugees who had clear memories about Paphos town, and (ii) the younger generation, who were born in Aşağ Maraş and had no relationship with Paphos town.

\subsection{Research site}

\subsubsection{Historical background}

According to historians (Keshishian, 1972, 1985; Loizou, 1954) the Walled city of Gazimağusa (Famagusta), in Northern Cyprus was established in the Lusignan period, which was between 1192 and 1489. The suburbs of Maraş (Varosha) and Așağ 1 Maras (Kato Varosha), were developed outside the walled city, and densely populated by the mid 19th century. The expansion took place predominantly towards Maraş in the British period (1878-1960) when this region was under Greek-Cypriot control. After the 1960s, when the Republic of Cyprus was established, the town of Gazimağusa expanded in both size and population towards the 
southeast of the Așağ Maraş and Maraş districts, the latter of which soon became an attractive tourism centre on account of its beautiful and relatively unspoiled coastline and beaches.

After the conflict in 1974, the Greek Cypriots completely abandoned Maraş and Așağ Maraş districts. The region's coastline area (Maraş), which mainly accommodated tourist facilities, was closed to the public and surrounded by a barbed wire fence by the newly established Turkish government. This area has remained a prohibited zone since 1974. The other district (Aşağ 1 Maraş), which has orange orchards and planned housing estates, was given over to refugees from both Southern Cyprus (Turkish Cypriots) and from the Turkish mainland. Today $22 \%$ of the inhabitants of the area are Turkish-Cypriot refugees from Southern Cyprus, 13\% are children of Turkish-Cypriot refugees and 65\% are immigrants from mainland Turkey and their children, who were born in the Aşağ Maraş district. Hence, today each settler in Aşağ Maraş is either a refugee or an immigrant, or a child of a refugee or immigrant. There are no original Gazimağusa citizens inhabiting this region. In order to examine the processes of forced relocation and because of their different cultural history and background, this paper focuses on the Turkish-Cypriot refugees and excludes immigrants from the mainland.

In April 2003, after 29 years of uneasy truce, the closed borders between Northern and Southern Cyprus were opened. Following this event, large numbers of Greek Cypriots visited Northern Cyprus, in order to see their 'homes' which they had been forced to abandon in 1974. The Turkish Cypriots also visited their former homes in Southern Cyprus, which they, too, had been forced to abandon.

\subsubsection{Rules and customs of the abandoned houses}

Initially, the houses in the Aşağ $\breve{1}_{1}$ Maraş district were assigned to the Turkish-Cypriot refugees to compensate for the lost ownership rights to the properties they had left behind in Southern Cyprus, following the intervention by the Turkish army in 1974. Those who had left behind large pieces of properties in the South were allocated relatively larger and well-maintained houses in the North. In 1986 the Government Council issued the "Equivalent Property Act," which sharpened the rules to include evidence of equivalency conditional to the property being assigned, and full legal property rights were granted to affected people.

\subsubsection{The old and new houses of relocated residents}

For the present study, one question is the extent to which the foreignness of the physical environment has been the issue. It is also important to note that, the locations and architectural characteristics of the two environments may play an important role with regard to the issue of the place attachment of the relocated residents. Therefore, descriptions of the old and new houses are provided in order to offer some clues about the possible limitations related to the place attachment patterns of the two environments.

3.1.3.1. Physical characteristics of the participants' houses: Aşağ Maraş houses. Through the observation of the researcher, it can be said that a typical Aşağ ${ }_{1}$ Maraş house consists of two or three bedrooms, a living room, a dining room and kitchen, which usually opens onto the back yard and the houses always have a small veranda at the front. Only the two-storey houses have balconies either to the front or the back. Most of the houses have roof terraces, which are generally used as regular, everyday spaces. In appearance, the participants' houses are of a similar type, with unique architectural features that are exclusively associated with the 'Modern Style'. They are constructed exclusively of reinforced concrete and brick and are one or two stories high. A skeleton type of construction was employed, using reinforced concrete frames and brick, infill walls. The facades of the houses have square shaped openings and generally present a rather drab appearance, painted mostly in light colors. There are, however, quite a number of facades which the original owners had decorated and enhanced with colored stone tiles, shutters, bow shaped windows etc. The houses are mostly of the semi-detached type surrounded by gardens on three sides. The house gardens are cultivated with flowers and fruit trees, and are mostly separated from one another, providing privacy between families. Gardens also form the street boundary through the use of low fences and shrubbery.

3.1.3.2. Physical characteristics of the original houses of study participants: Paphos houses. Our knowledge of participants' original homes in Paphos is very limited. After the fragmentation of the country, the Greek-Cypriot government did not settle any refugees in the Paphos houses abandoned by this study's participants. Their houses were left empty and neglected, and today, after 34 years, most of them have been either demolished as a result of damages suffered from the war, or they are in a very bad physical and structural condition due to lack of maintenance. Therefore, our knowledge of their design and appearance is minimal.

Following a brief visit by the author to Paphos town, and with the helpful guidance of some of the participants of the study, as well as information gathered from informal interviews with the Paphos refugees, it can be inferred that the original houses of this study's participants were generally constructed from mud-brick or stone, covered with plaster or concrete, painted white, planned and developed in an organic fashion on the hills of Paphos town. The participants described the general development process of their original houses thus: "When a person got deed's title full development right, at the beginning s/he constructs only one room at the back of the site. Later, a WC was added to it. As the time goes by, according to the increasing number of family members and their needs, other rooms were added to previous rooms and the house gains its final layout." This definition and description convinces us that those houses were typical examples of the 'vernacular' architecture of Cyprus. A typical Paphos house is said to generally have a central courtyard. The houses were mostly of the detached type surrounded by gardens on four sides. Usually they were one or twostorey high with flat roofs. Today there are still orange orchards and gardens around these houses.

\subsection{Methods}

Many researchers have proposed qualitative research tools in addition to qualitative, in order to study the social world (see Denzing \& Lincoln, 1994). Hence, this study is based on the results of a questionnaire survey, semi-structured interviews and mental mapping in a selected environment. This process and method will be explained in detail in the following text.

\subsection{Sampling and procedure}

\subsubsection{Sample selection}

In selecting the sample neighborhood for this study, some basic criteria were followed. Initially, the availability and/or accessibility to the material evidence to support the information about the structures was researched. Second, a culturally homogeneous group of people was identified. The study street ${ }^{2}$ was selected

\footnotetext{
${ }^{2}$ Indeed the name given to the area following the resettlement of the Turkish Cypriots means "war veteran from Paphos".
} 
because each family living there originated from Paphos and, therefore, had the same cultural background: they are 100\% Turkish Cypriots and $100 \%$ Muslim. There is no other concentrated refugee group living in Aşağ Maraş. Other residents comprise mixed groups of refugees and immigrants from various cities on both the Turkish mainland and south of the island.

\subsubsection{Participants}

In 2006, forty people between the ages of forty nine and eighty two, and twenty people between the ages of eighteen and thirty two participated in this study. All shared a common religious and cultural background. The older participants were middle-income with varied occupations, including teachers, policemen and businessmen (employers). The younger participants had all been born and raised in this neighborhood. Eighty percent of the younger participants were either university students or university graduates. The remaining $20 \%$ had completed high school and were employed. All but five were single and still living with their parents. Demographics are offered in Table 1.

\subsection{Data collection procedures}

In order to examine the degree of place attachment to this environment of both the old and young people, information was sought with respect to how the participants felt about living in the residences as well as the surrounding neighborhood. The field surveys conducted between the 10th May and the 15th June 2006 are as follows: (i) site inspection and audio-recorded interview, and (ii) a questionnaire.

Forty houses were selected as the sampling frame. Two types of questionnaires were designed so as to elucidate and identify the general characteristics of place attachment of people (both young and old) to their homes and their immediate surroundings or environment.

The first type of questionnaire was distributed by the author, who visited each house in the sample area, and obtained a total of 60 participants (40 older and 20 younger participants). The cooperation of each household member was sought by securing the prompt return of the questionnaire after helping the participant to read and understand the questions etc.

Table 1

Demographic characteristics of the participants.

\begin{tabular}{lll}
\hline Ages & $49-82$ yrs $(N=40)$ & $18-32$ yrs $(N=20)$ \\
\hline $\begin{array}{l}\text { Nationality (\%) } \\
\text { Turkish Cypriot }\end{array}$ & 100 & 100 \\
Sex (\%) & & \\
Female & 65 & 50 \\
Male & 35 & 50 \\
Birthplace (\%) & & \\
Paphos & 100 & - \\
Gazimağusa (Famagusta) & - & 100 \\
& & \\
Education (\%) & 5 & - \\
Elementary & 15 & - \\
Secondary & 55 & 20 \\
High school & - & 50 \\
University students & 25 & 30 \\
Graduate & & \\
Length of Residence (\%) & - & 15 \\
22 yrs & - & 15 \\
25 yrs & - & 20 \\
26 yrs & - & 20 \\
27 yrs & 100 & 25 \\
29 yrs & & 5 \\
32 yrs & & \\
\hline & &
\end{tabular}

Five open-ended questions were included in this questionnaire, designed to probe the general characteristics of young and old participants' attachment to their homes and their immediate environment. The questions included:

- "Are you happy with your house? (Why)"

- "Are you happy with your street? (Why)"

- "Can you call this place 'home'?"

- "How often do you maintain your house?"

- "Where would you like to live in the future, here or elsewhere (specify)?"

Participants were also asked to answer an additional five questions, which were designed to provide information about the issues of place dependence, on the basis of the five-point Likert scale (strongly agree, disagree, undecided, strongly disagree.). The Likert-type scale method was used in this instance because using this type measure in previous place attachment studies proved very successful in the past (see Williams \& Vaske, 2003). The Likert scale statements were:

- "This place means a lot to me"

- "I cannot be away from my house for a long time"

- "I wouldn't substitute any other area for my life here."

- "I've been missing my birth-place"

- "If a had the chance I would prefer to continue to live my life in Paphos from that moment"

The second type of questionnaire was in the form of open-ended questions, which were only distributed to younger members of households in order to, in the same way, identify the feelings of those younger people who had no relationship with Paphos, the birthplace of their parents. This group of participants were born and brought up in the sample environment and, therefore, their experiences of the environment in which they all lived differed from that of their parents. The reason for asking these participants further questions was mainly to expose their differing patterns of place attachment. The open-ended questions, which were put to 20 young people, were as follows:

- "What are your hobbies and special interests?"

- "Do you think that your house is designed to accommodate your special interests?"

- "Does the location of this street and its social/public areas meet your needs?"

- "Are you happy to live in this quarter?"

- "Do you know everyone in your street?"

- "Where would you like to live in the future? (Why?)"

Beside these questions, each participant was asked to draw a picture of their ideal 'home', a map of their current home and its location within the immediate vicinity, including the street that it fronted and the important buildings nearby. This 'mental mapping' was selected as a method to measure participants' store of spatial knowledge about their previous and current environments. Since a mental map is based upon personal experience within an area and an individual's selective representation of their known world (Kitchin, 1994), in the present study, it was predicted that the mental drawings of participants would help us to better understand the direct experience of people and their settings with respect to their attachment.

A more detailed structured interview study was also designed and carried out with a subsample of 40 people ( 20 older and 20 younger residents) in order to study attachment within its context. All participants were interviewed individually in their houses. These interviews lasted about one hour. 


\section{Results and discussions}

\subsection{Strategy of analysis}

For the purposes of this study, the data analysis involved separately identifying, coding, and categorizing patterns found in the data, for each participant group (old and young). Information gathered from the questionnaire surveys was converted into short and simple statistical significances. Numeric results from the Likert scale questions are provided in Appendix 1 for each group of participants. A considerable amount of data was obtained from interviewing and observing research participants. During the interviews, the author focused on the issue of understanding the lived experience of the participants. First, the interviews were analyzed separately for each participant. Then a set of common themes was identified and the interviews reanalyzed to identify all comments related to these themes. Participants' drawings are interpreted by the author vis à vis information gathered from the interviews, and are used to show what participants had in their mind as an image of an ideal 'home.' The ideal home should represent their identity and give us clues about their attachment process.

\subsection{Patterns of place attachment}

\subsubsection{Attachment of older people to their current environment}

Previous literature generally indicates that the attachment of people to their built environment takes the form of a relationship between the people and the environment in question in whatever context, and the way it develops very much depends on the familiarity and/or foreignness of the environment and the length of time that the people may have invested in it (Taylor, Gottfredson, \& Brower, 1984). The problem as viewed by Tuan is that: "Settlers perceive their new environment through the tinted glass of past experience. Once people have settled down and adapted somewhat to the new setting, it is difficult to know their environmental attitudes for, having become native, they lose the urge to make comparisons and comment on their new home." (Tuan, 1974, p. 68). It has also been suggested that, after living in one place for many years, familiarity breeds acceptance and even attachment (Taylor et al., 1984). However, in this study, it was found that Paphos refugees have not adjusted to their new homes even after 34 years.

When reflecting on their experiences upon arriving in Așağ Maraş, the general feeling expressed by the Paphos refugees about their new settlement, streets and homes was positive. The refugees came from organically developed vernacular houses in Paphos and moved to the pre-planned modern houses of Greek Cypriots. During the interviews, $90 \%$ of the participants mentioned that they were all impressed with the architectural characteristics of the Aşağ $\breve{1}_{1}$ Maraş houses. For many their initial judgment had not altered much up to the present time. In fact, when asked whether or not they were satisfied with the street in which they have continued to live up until today, the majority (70\%) indicated that they were satisfied, and an additional seventeen percent indicated that they were moderately satisfied. However 3\% indicated that they were not at all satisfied. Those who were not satisfied with their street mentioned that they could not establish strong relationships with their neighbors as they had done in their former environment. This is consistent with other research showing that involuntary relocations are very disruptive to neighborhood relationships (Brown \& Perkins, 1992).

Although the open-ended responses were generally positive with regard to the level of satisfaction with the street environment and the houses, the Likert item revealed that only one out of 40 participants would strongly agree with the statement: "This place means a lot to me". A majority (15/40) strongly disagreed with the statement. The 24 who agreed are the people who still remembered the 1974 intervention. They did not want to go back to Paphos, saying that everything had changed there, and whether they wanted to return or not, they had to live here and this place was now 'home' for them. Similarly, when asked whether they could refer to their current houses as 'home', $90 \%$ of the respondents gave negative answers. Those few who answered the question positively were older (ages ranged from 60 to 82), and all expressed a similar theme:

"We do not expect anything more from life. Our children have married here, in Mağusa, leaving us alone as lonely couples in our homes. We still remember our days in the war and carry the fears of those days with us and we do not want to go back to the homes we remember only with bitterness. This is our home now and will stay so forever." (Gulsen Yenen ${ }^{3}$, female, 72 yrs).

In brief, therefore, although the majority of participants were all satisfied with the physical characteristics of their new houses, they have difficulty identifying themselves with their new homes. Within the literature, Moore (2000) has explored the processes through which homes develop meaning. As mentioned previously, the process of transforming a house into a 'home' is a continuous process, which develops in parallel to accommodating the social and physical relationships with that place. In the present situation, the social 'foreignness' of the refugees with respect to their new community seems to play a much more significant role than the physical 'foreignness' of the actual new houses. As a consequence, their current setting, did not provide participants with the opportunity to express their identity. It should also be noted that currently, refugees from Paphos still refer to themselves as: 'Bafli', which means 'Paphos citizen.' Thus, despite their migration to Gazimağusa having taken place thirty four years ago, it appears that the refugees still identify with their previous environment.

In addition, when asked to express the degree of their feelings about the statement: "I cannot be away from my house for a long time", their answers varied. But, it was observed most clearly that most of the participants would prefer not to move to another place, especially one outside their own area. In addition they expressed a common feeling that, as refugees they had had enough experience of moving from one place to another and that they had no desire to leave this particular place.

The majority of the participants stated that they missed their birthplace: "There we had everything, now here we have nothing!" (Melda Isak, female, 46 yrs). After boundaries were opened between North and South Cyprus, $44 \%$ of the refuges went to visit their houses in Paphos. Most (75\%) of these houses had either been demolished or were in very bad states of repair. This had a negative effect on those refugees.

\subsubsection{Attachment of older people to their previous environment}

As discussed in previously, people describe themselves in terms of belonging to a specific place (Stedman, 2002) and attachment to a place becomes a unique and deep emotional bond, which is not easy to substitute or replace. Part of our aim in this survey is to determine the attachment of the residents to their former home and environment. The critical question in this connection was whether their present homes afforded them an image of an ideal home. From the questionnaire survey it was discovered that the homes that were left behind in Paphos were clearly the representation of an ideal home for the majority of respondents (90\%) (see Figs. 3-6).

\footnotetext{
${ }^{3}$ In this paper, names are fictitious to protect participants' identities.
} 
This result was not a surprise because people need to experience the environment as offering a pattern or a system of meaningful relationships and in order to achieve this they use their previous experiences and time (Ittelson, 1960). As Tuan states: "Awareness of the past is an important element in the love of a place." (Tuan, 1974, p. 99), hence past experiences and the memories of those experiences manipulate the development of place bonding (Rowles, 1983; Vorkinn \& Riese, 2001). Experience is required for the full development of three-dimensional vision. In a continuous process, the development of perception and the patterns of human behavior are the results of the mind receiving, processing, storing, and producing environmental information.

When asked to draw their ideal place and 'home' on a piece of paper none of the participants was willing to draw their present street or house as their ideal 'home'; they preferred to draw the streets and homes they had left behind in Paphos, which they did with great care down to the finest detail (see Figs. 3-6). In addition to their drawings of their former homes, they not only drew their houses within their environmental context, but they also included the nearby houses and shops. Furthermore, they said that they remembered many more details in their mind than those which they included in their drawings.

People's 'place attachment' develops and matures just as their self-evaluation process does (Piaget \& Inhelder, 1956). Therefore, the place where we grow up and spend our childhood can strongly inform our concept of the ideal environment. In other words, "one's birthplace is part of one's identity" (Oliver-Smith, 1986, p. 52, cited in Brown \& Perkins, 1992, p. 293), which describes the situation for the Paphos refugees.

Mustafa Kivanc, who drew Fig. 3, was a 23 year old man when he had to leave his home town of Paphos. In his drawing of his 'ideal home', he pointed out a primary school in detail (which is located in the top-left corner of the picture), two gardens, (one with orange trees), which, he stated, were full of memories and his house which stood in the top-right part of his drawing.

Sevil Engin, on the other hand, was 18 years old when she had to move from Paphos to Aşağı Maraş. In her drawing (Fig. 4), she tried to represent the hilly terrain of her original home environment. She pointed out a 'primary school' at the top of the hill, a hospital (under the primary school), houses which stood side by side called 'Göçmen houses' and she marked her own house with a cross. She also pointed out the sea, which was located on the left side of her drawing.

Another participant, Dr. Halil Adem was 23 years old when he had to leave his home and, as the author guessed from his drawing (Fig. 5), he was Sevil Engin's neighbor. This information was not mentioned by any of the participants during the interviews. But in

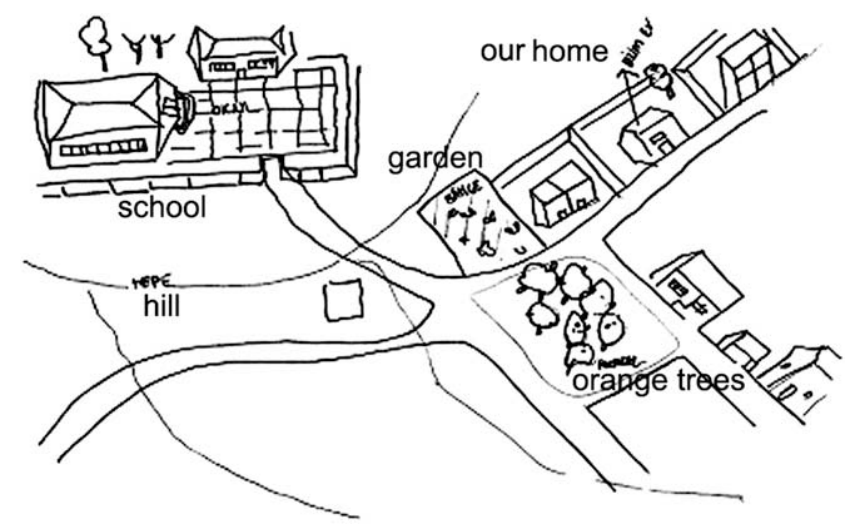

Fig. 3. Resident's drawing of an ideal 'home' and surroundings: Paphos. Drawing by Mustafa Kivanc (male, age 55 yrs).

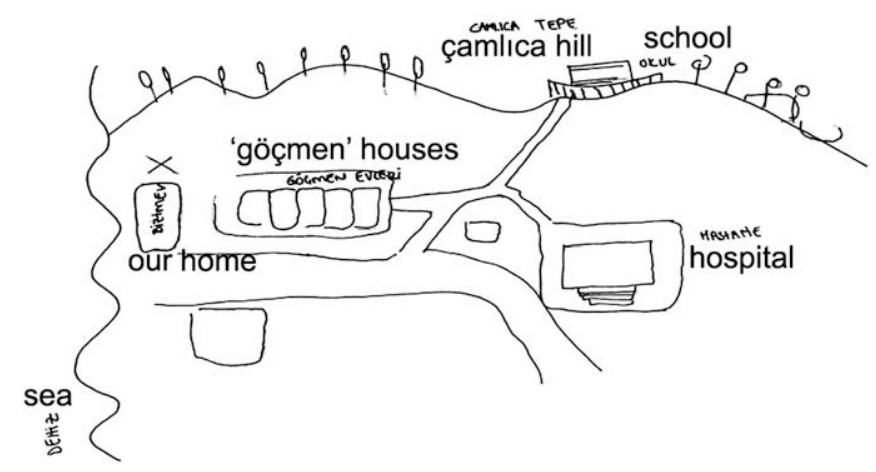

Fig. 4. Resident's drawing of an ideal 'home' and surroundings: Paphos. Drawing by Sevil Engin (female, age 50 yrs).

Dr. Halil Adem's drawing, the hospital image, represented by both him and Mrs. Sevil Engin, was identical, as were the 'Göçmen houses' standing side by side. Dr. Halil Adem had marked one of these houses as his 'home' in Paphos. In his drawing, he also wrote the names of the places where each road went.

Melda Isak was only 13 years old, when she had to leave Paphos with her family (Fig. 6). Although she was the youngest refugee participant of this study, she was also the only one who drew a plan of the layout of her house (bottom-right of Fig. 6) in detail. Other participants have concentrated more on the location and the surroundings of their homes. Mrs. Isak also depicted other buildings which she remembered, such as a coffee shop, a dormitory, the British military camp, the bazaar and some other shops. When she was asked why she preferred to draw her Paphos house as an ideal 'home' rather than the house in which she was currently living, she replied that:

"There was a picture of myself when I was 6 years old in the living room of our Paphos home. My mother and fathers' wedding day photos... We left them behind! We left everything behind there in wartime. Now, I don't have any pictures from my past. How can I call a place 'home' if I do not have a picture of my childhood on the wall, or of my parents from their past?" (Melda Isak, female, 46 yrs).

Many participants described similar feelings and they also mentioned that when they first settled in these foreign houses, one of the first things they did was to remove the family pictures of Greek-Cypriot residents from the walls and put them in a safe place. Soon after they settled, the participants reported that they all sent the pictures to their owners or kept them safely until the day that

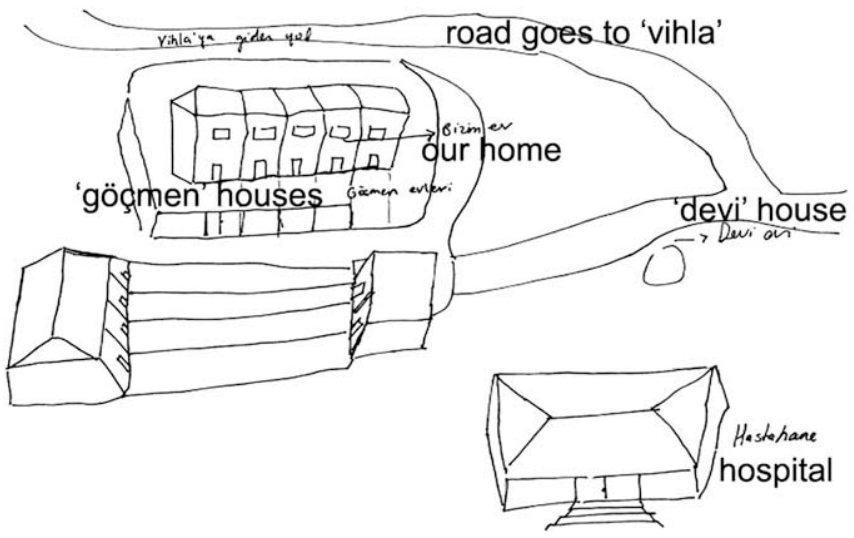

Fig. 5. Resident's drawing of an ideal 'home' and surroundings: Paphos. Drawing by Dr. Halil Adem (male, age 50 yrs), 2006. 


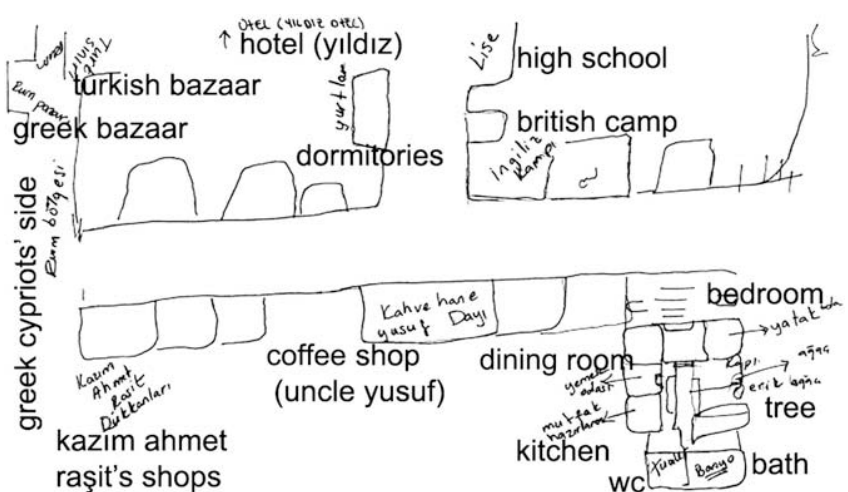

Fig. 6. Resident's drawing of an ideal 'home' and surroundings: Paphos. Drawing by Melda Isak (female, age 46 yrs).

the Greek-Cypriot owners of the houses returned to visit their homes. Interestingly enough, they said they didn't receive any of their pictures from their former homes. As boundaries are opened, similar visits and returning of photographs and belongings are still happening today, which have proved to be a very popular issue for the press.

The emotional attachment of the participants to their Paphos homes has never ceased. On the contrary it has persisted and continued to grow, whilst they also invested many years in their new environment and also developed some form of attachment to this new environment, and as several authors have demonstrated place bonds develop over time in response to an individual's interaction with their environment (Hay, 1998; Milligan, 1998).

\subsubsection{Attachment of younger people to their current environment}

It is part of the design of the present study to investigate the differences in felt attachment to Aşağ $\breve{1}_{1}$ Maraş between the refugee settlers and the later generations who grew up in this new environment. Obviously the latter group consists of the children and the grandchildren of the first generation of refugees, who migrated into the area. This group's emotional ties to Paphos have been limited to the stories and personal accounts of their parents and/or grandparents. The group is mainly twofold. The first group, which consisted of people in the age range 18-32, had heard more of the direct stories and personal accounts of Paphos from their parents than the second group, which consisted of younger people in the age range 11-17. It is clear from the in-depth interviews with the subgroup that the first group used the streets in Așağ ${ }_{1}$ Maraș more than the second group. The Aşağ 1 Maraş streets were used by the former group mainly during their childhood as playgrounds and as tracks for riding bikes... etc. It was observed that the streets of Aşağ $\breve{1}_{1}$ Maraş streets afforded the local children a number of possibilities and facilities for use in their free time. As a young man said:

"We were ten naughty children riding our bicycles to the gardens. We met there with other guys from other streets and played games. Everybody knew each other. It was a lot of fun." (Kemal Agit, male, age 29 yrs).

The present study was concerned only with the first group's place attachment, and a number of open-ended questions were put to 20 participants within this age group (18-32). In addition, these participants were asked to draw their view of their ideal home (Figs. 7-10). Results of the questionnaire (type 1) survey (sample size: 20) are provided in Appendix 1. The 11-17 year olds were not included in the questionnaire survey, nor were they asked to draw their ideal homes. A younger group (aged 5-10) did not answer questions but was asked to draw their homes.
Responses revealed that the majority of the 20 participants would strongly agree with the following statement: "This place means a lot to me" (12/20). The importance of social relationships vis à vis the environment and the attachment process has been mentioned by Hidalgo and Hernández (2001). In this case, due to their strong relationship and continuous involvement and interaction with their present environment the younger generation mentioned that this place was 'home' for them, whereas this was not the case for their parents.

When asked to express the degree of their feeling about the statement; "I cannot be away from my house for a long time", a majority (12/20) also strongly agreed, whereas 3 said they disagreed and the rest varied. For many, like their parents, most of these participants would not like to move to another place.

Although those people interviewed stated that they did many things in their environment during their childhood, the younger participants also gave varied responses to the statement: "I would not do without this street as it gives me the freedom I want for the things I do around my home." All 20 participants stated that they would not want to live in Paphos, the birthplace of their parents, if they had the opportunity to return there.

The interviews conducted revealed that the participants had established strong ties with the locality/environment in which they had grown up. Paradoxically, however, the participants further indicated that they were not happy living in this environment, mainly because their street/neighborhood did not offer any public space they could use for entertainment and social gatherings. Nearly all of them indicated that they liked going to the cinema, but complained that there was no local cinema in the vicinity, the nearest one being a 20 min drive from their homes. Furthermore, they reported that there were no other entertainment facilities to meet their social needs. Nevertheless, both the emptiness of the streets and the multitude of garden trees and plants (such as jasmine) in the district, were appreciated. Indeed, the gardens with their plants and other amenities appeared to be the primary basis of participants' emotional ties to the area. Burcu Kose stated:

"When we smell it (jasmine), we feel happy and like this place, and we sometimes think that we are happy there, and why shouldn't it be our home then? We want an immediate solution for the whole island. We do not want to live with the fear and worry about whether they will remove us from our houses for political reasons, or whether the Greek Cypriots will return to their original homes, which are our homes now." (Burcu Kose, female, age 26 yrs).

A commonly held belief amongst the young people is that they feel that these houses do not really belong to them and this,

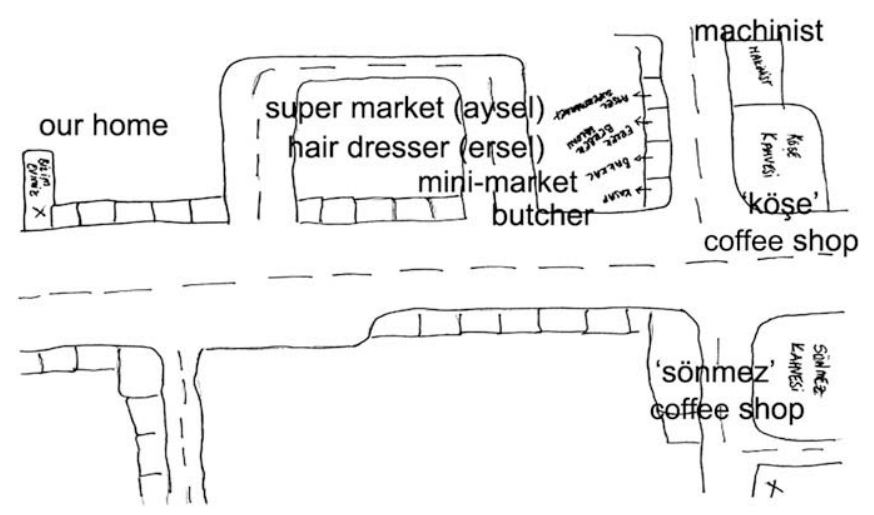

Fig. 7. Residents drawing of their ideal 'home' and surroundings: Așağ Maraş. Drawing by Burcu Kose (female, age 26 yrs). 


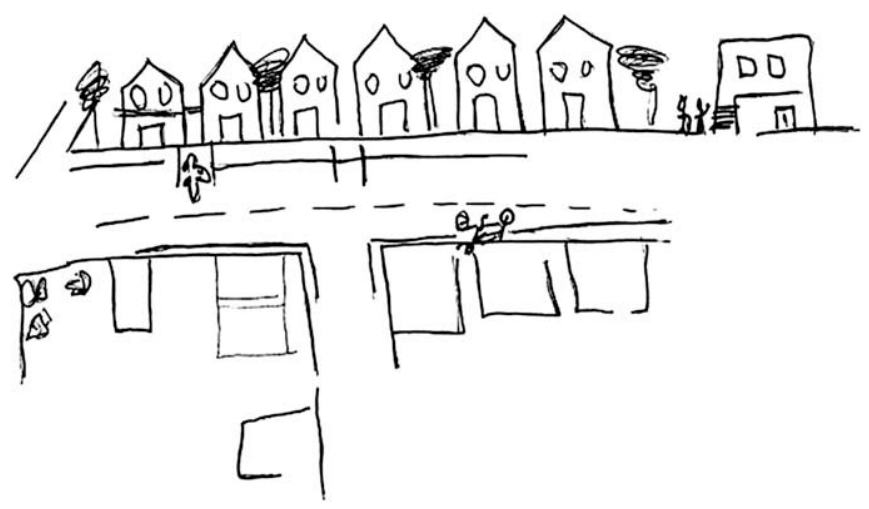

Fig. 8. Residents drawing of their ideal 'home' and surroundings: Aşağ 1 Maraş. Drawing by Fikri Emin (male, age 32 yrs).

naturally interferes with and frustrates their feelings of attachment. Moreover, it was observed that the lack of social facilities within reasonable proximity to their neighborhood also frustrates their feelings of attachment to the district, since they spend less of their free time there than in other places which have better social facilities.

This statement was also reflected in the participants' ideal image of 'home'. When they were asked to draw their houses and surroundings, the younger participants, unlike their parents, did not provide much detail or show much interest in how they depicted their houses and surroundings. Furthermore, hardly any of them marked their house as theirs in the drawings.

Burcu Kose was the only participant, who depicted nearby buildings in her drawing (Fig. 7) such as, two coffee shops on opposite sides of a road (Sönmez Kahvesi and Köşe Kahvesi: left hand side of the drawing), a small market, a butcher and so on. She also marked her own house, which was located in the top-left section of her drawing.

Fikri Emin, on the other hand, preferred to draw his actual home from a memory of his childhood (Fig. 8), as he remarked whilst drawing. He did not, however, give any information about buildings nearby or indicate his house.

Ali Sedat's drawing (Fig. 9), on the other hand, was a typical example of a younger participant's image of their ideal home and surroundings. There was no information about any of the structures in his drawing.

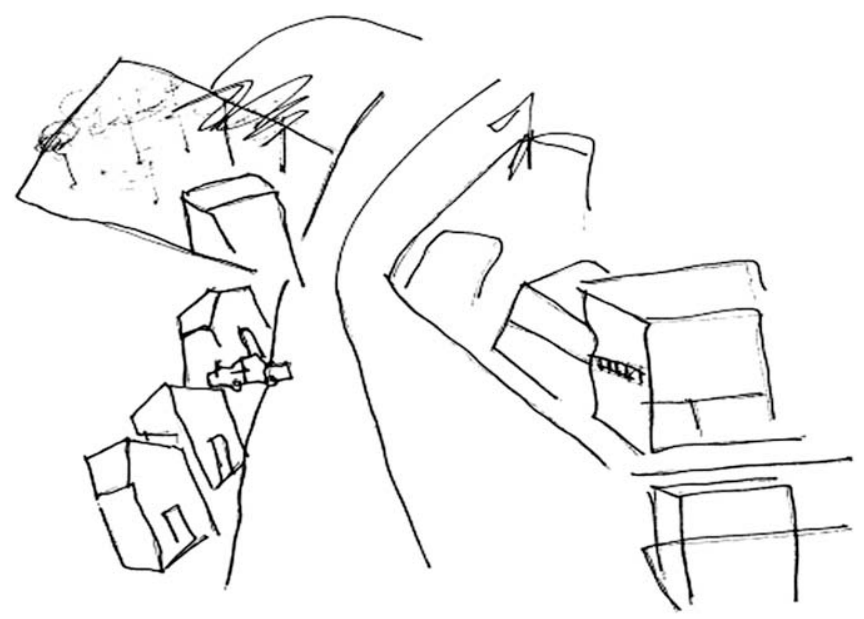

Fig. 9. Residents drawing of their ideal 'home' and surroundings: Aşağ $\breve{1}_{1}$ Maraş. Drawing by Ali Sedat (male, age 29 yrs).

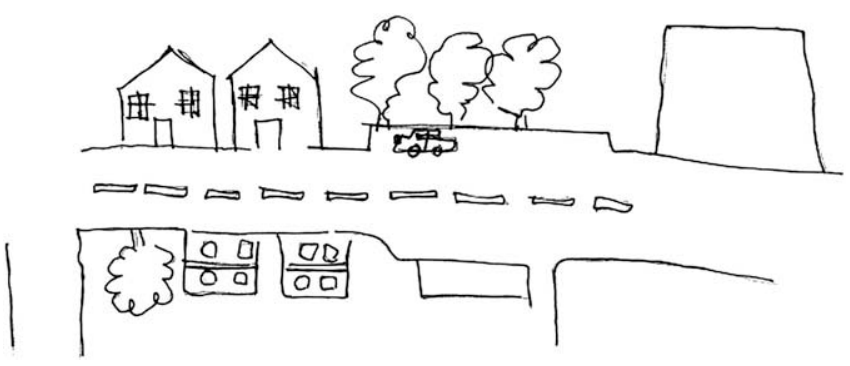

Fig. 10. Residents drawing of their ideal 'home' and surroundings: Aşağ Maraş. Drawing by Kemal Agit (male, age 29 yrs).

As with Ali Sedat, Kemal Agit also did not give any extra or detailed information about his house and surroundings in his drawing (Fig. 10). He only depicted four buildings on his street from a total of 40 structures.

The survey revealed that majority of participants who fitted into this age category felt much more attached to their environment than their parents did. Nevertheless, the majority of the participants indicated that they would prefer to live in a district other than Aşağ 1 Maraş. 65\% of the respondents answered positively to the question: "Would you like to live in a different district in the future?" The most common reasons given by the participants for their positive answers included the uncertain future of the island and the fact that the houses are given over to their parents and that they also might be forced to live in another place at some point in the future. Thirty-five percent of the participants, who responded to the question negatively, felt very attached to the district. A statement made by Selin Oz clearly demonstrates this:

"We grew up here. Everywhere is full of memories. If an agreement is signed between the Greek and Turkish Cypriots and the prohibited section of Maras district is opened up for public use, everything will be perfect! I wouldn't leave my home then for another place." (Selin Oz, female, age 21 yrs)

Although the other age groups comprising teenagers (ages between 11 and 17) and children (ages between 5 and 10) were not included in the site survey, the younger group of children were asked to draw their 'home' and its surroundings (Figs. 11 and 12).

The drawings done by children (Figs. 11 and 12) showed that their memory of home space is very limited or non-existent; since their drawings did not depict any similarity to their actual houses, which might be the basis for further research. For example, Cem Kivanc (male, 7 yrs) drew a two-storey house with a big tree nearby (Fig. 11). In reality, however, his home is a one storey detached house. Lale Erman (female, 8 yrs) on the other hand, however, who

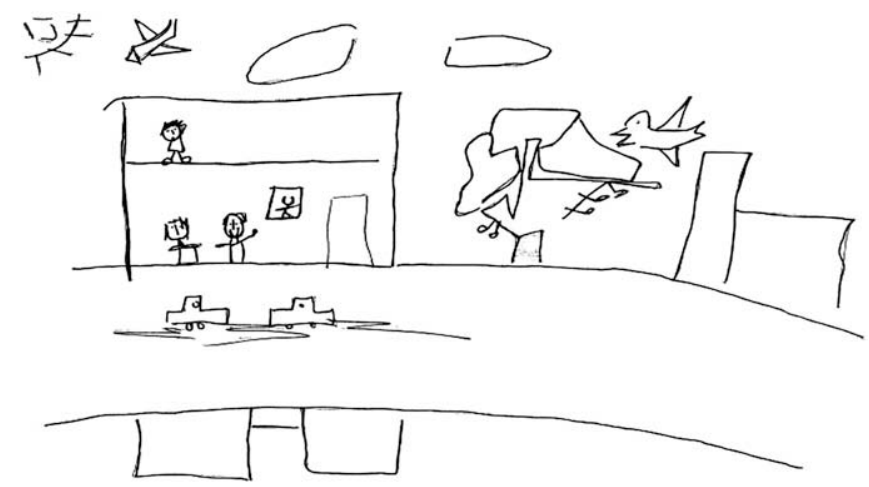

Fig. 11. Resident's drawing of their ideal 'home' and surroundings: Aşağ Drawing by Cem Kivanc (male, age 6 yrs). 


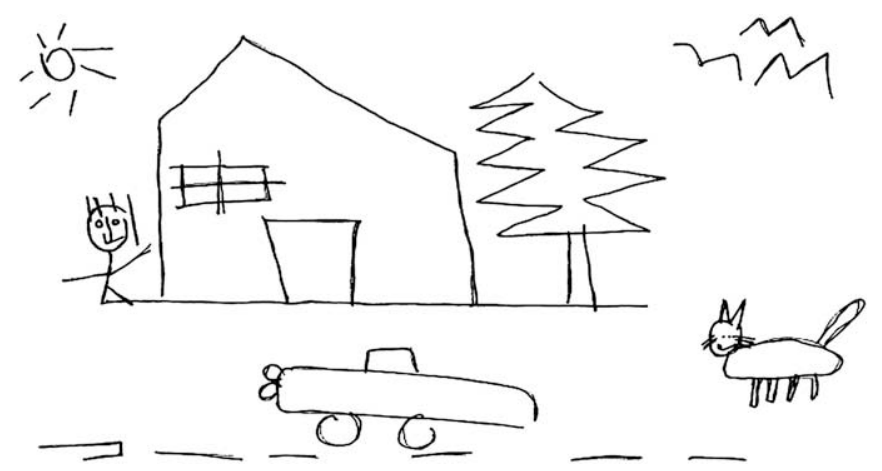

Fig. 12. Residents drawing of their ideal 'home' and surroundings: Aşağ $\breve{1}_{\text {Maraş. }}$ Drawing by Lale Erman (female, age 8 yrs).

lives on the first floor of a two-storey semi-detached house, drew a single storey house with a sloping roof (Fig. 12).

\section{Conclusion}

As demonstrated by previous research, this study has revealed that peoples' past experiences, whilst acknowledging their involuntary relocations, play a major role in their feelings of attachment to a particular place. Paradoxically, however the familiarity of living in an environment for over thirty years did not appear to foster a particular attachment as was postulated in previous studies. Attachment is a process in which people 'fall in love' with a place (Schward et al., 1995) and this love cannot easily be traded for a new one. As discussed above, the majority of the older participants stated that they missed their birthplace and the houses they left there, which represented their ideal 'homes'.

Each refugee has memories of their childhood environment and, therefore, they believe that that place is their true homeland. Rather than the location or physical characteristic of the houses, it is the emotional ties between them and their homes that have played a much greater role in their attachment process. Today, they only live in their current place in order to survive. Interestingly enough, although the patterns of place attachment of this generation to their current environment are weak, they are not willing to live in another place in the future. After all considering their past traumatic and sad experiences, it would not be easy for them to leave their homes again.

The degree to which participants felt attachment to their past environments played an important role in any future attachment processes, but future expectations, actually, tended to be more influential in shaping their attachment to their current environment. To some authors, the strength of the attachment depends upon an evaluation of the current situation (Giuliani, 2003). People usually tend to judge whether a setting supports their goals and purposes (Winkel, 1981) over a long period. Under these circumstances and not knowing what will happen in the future very much affected the participants' attitudes towards the existing environment in every aspect.

Another interesting result of the study was that the participants were very well aware when they took up residence there that the houses had been the property of people from another culture, and that these houses were held in the memories of the previous occupants. Thus it transpired that they always had the feeling that they were living in the houses in Așağ $\breve{1}_{1}$ Maraş as guests, as if these houses had been entrusted to them by their Greek-Cypriot owners; they realized that the situation was much more complex than it appeared. Each time participants alluded to the previous inhabitants of the houses, during the interviews, they insisted on describing them as the 'real owners' of the houses. The participants, who had been displaced from their own houses, showed particular care and interest in saving the personal belongings of the 'real owners' of the houses to which they were allocated. As previously mentioned, it became clear, during the interviews that these people felt that belongings, such as family albums or pictures are what make a place a home. In this study, the concept of 'home' was the primary component in respect of the issue of place attachment. For many years, almost all of the residents of Aşağ Maraş hoped that the day would eventually come when they could all return to their own houses in Paphos. Visiting their old homes and locality in Paphos in 2003, and being unable to find any of their old belongings or, in some cases, even their former homes, had a dramatic effect on the lives of these people. As Sevil Engin said, who accompanied the author during her visit to the Paphos houses:

"Finally we understood that we don't have a 'home' to return back one day. Our houses are demolished and now we have been all alone only with the memories of our homes. But still we wish that we would still be living in Paphos!" (Sevil Engin, female, age 50 yrs).

Surprisingly, these events served to emphasize and bolster their attachment to their original environment; to date they still picture Paphos as a 'dream environment' in their mind's eye.

The findings of the study also demonstrated that, although the younger generation is more attached to their current environment than the older generation, the majority of both age groups did not feel able to look to the future, plan ahead, or have specific expectations about their current homes and locality. Giuliani and Feldman (1993) suggested that the issue of place identity involves a psychological investment in a place that develops over time. Gerson, Stueve, and Fischer (1977), on the other hand, claim that social relationships in a neighborhood help to develop a sense of belonging. The younger participants used their current environment during their childhood, which strengthened their attachment to Așağ 1 Maraş. However, since their institutional ties, social activities and interactions within the environment have waned over time, the current environment no longer supports their self-identity. In this respect, the setting has failed to offer them the opportunity or possibility of expressing and consolidating their identity. A reference to this result can be found in Hernández et al.'s (2007) statement: “... one person could be attached to a place but not be identified with it (i.e. someone who likes to live in a place and wants to remain there but does not feel that this place is part of their identity; at least not their main place identity) and vice versa...". The thought that: "these houses have been given to us and will, one day, perhaps, be taken away", still affected the feelings of the younger generation, to the extent that most of these people stated that they would not be willing to live in this environment in the future.

The results of this project capture complex feelings about forced relocation, loss of home, and discomfort at occupying others' homes and how these experiences are reflected in lack of deep and enduring attachment to their homes even after 34 years of residence. However, it is important to remember that this is a select group of participants, and these findings may not generalize to others, even in similar situations. Also, it cannot ignored that lack of attachment the participants attribute to the difficulty of their situation could simply be due to other unrecognized inadequacies of the physical or social environment. Information from children born in or after 1974 to responses of their parents addresses this somewhat, because they liked the neighborhood and appreciated its physical and social qualities. Although it would have provided a useful comparison group, migrants and their children (not refugees) from the same street were not available. 
In conclusion, therefore, the author of this paper believes that the findings of this study could provide some interesting insights and identify major implications for the current world situations, including relocations, which have taken place in many countries, including Kenya and Israel. In Așağ 1 Maraş, even 34 years later, people's original houses still represent the image of 'ideal home', which makes us realize that providing adequate housing for refugees does not assuage the feelings of loss and alienation. Although some of the residents have lived in the Aşağ 1 Maraş houses for over thirty years, and have grown very accustomed to them, they were still not able to say, "This is my home."

\section{Acknowledgements}

The author is grateful for the generous help of Professor Carol Werner for reviewing this study and for her constructive comments besides detail suggestions about the improvement of the language of the paper. The author also would like to thank Dr. Saim Nalkaya for his intellect and support during the earlier drafts of the paper. Thanks also go to the anonymous reviewers for their helpful comments and insights.

\section{Appendix 1. Results of the questionnaire (type 1) survey for old and young people}

\begin{tabular}{|c|c|}
\hline $\begin{array}{l}\text { For older people (aged between } 49 \text { and } \\
82 \text { ), sample size: } N=40\end{array}$ & $\begin{array}{l}\text { For younger people (aged between } 18 \\
\text { and } 32 \text { ), sample size: } N=20\end{array}$ \\
\hline $\begin{array}{l}\text { "This place means a lot to me" } \\
\text { Year: } 2006 \\
S A=1 \\
A=4 \\
U=11 \\
D=9 \\
S D=15\end{array}$ & $\begin{array}{l}\text { "This place means a lot to me" } \\
\text { Year: } 2006 \\
\text { SA }=14 \\
A=1 \\
U=3 \\
D=2 \\
S D=0\end{array}$ \\
\hline $\begin{array}{l}\text { "I cannot be away from my house for } \\
\quad \text { Year: } 2006 \\
\text { SA }=8 \\
\text { A }=7 \\
U=14 \\
D=2 \\
\text { SD }=9\end{array}$ & $\begin{array}{l}\text { "I cannot be away from my house for } \\
\text { a long time" } \\
\text { Year: } 2006 \\
\text { SA }=12 \\
\text { A }=3 \\
U=1 \\
D=1 \\
S D=3\end{array}$ \\
\hline $\begin{array}{l}\text { "I wouldn't do without this street as it } \\
\text { gives me the freedom I want for the } \\
\text { things I do around my home." } \\
\text { Year: } 2006 \\
\text { SA }=0 \\
A=0 \\
U=7 \\
D=7 \\
S D=26\end{array}$ & $\begin{array}{l}\text { "I wouldn't do without this street as it } \\
\text { gives me the freedom I want for the } \\
\text { things I do around my home." } \\
\text { Year: } 2006 \\
\text { SA }=8 \\
\text { A }=1 \\
U=5 \\
D=6 \\
\text { SD }=0\end{array}$ \\
\hline $\begin{array}{l}\text { "I've always missed my birth-place" } \\
\text { Year: } 2006 \\
\text { SA }=28 \\
A=10 \\
U=0 \\
D=0 \\
S D=2\end{array}$ & $\begin{array}{l}\text { "I've always missed my birth-place" } \\
\text { Year: } 2006 \\
S A=- \\
A=- \\
U=- \\
D=- \\
S D=-\end{array}$ \\
\hline $\begin{array}{l}\text { "If I had chance to choose, I would } \\
\text { prefer to live the rest of my life in } \\
\text { Paphos rather than in Aşağ Maraş." } \\
\text { Year: } 2006 \\
S A=20 \\
A=0 \\
U=0 \\
D=0 \\
S D=20\end{array}$ & $\begin{array}{l}\text { "If I had chance to choose, I would } \\
\text { prefer to live the rest of my life in } \\
\text { Paphos rather than in Aşağ Maraş." } \\
\text { Year: } 2006 \\
S A=0 \\
A=0 \\
U=0 \\
D=0 \\
S D=20\end{array}$ \\
\hline
\end{tabular}

Key: $\mathrm{SA}=$ strongly agree; $\mathrm{A}=$ agree; $\mathrm{U}=$ undecided; $\mathrm{D}=$ disagree; $\mathrm{SD}=$ strongly disagree.

\section{References}

Altman, I., \& Gauvain, M. (1981). A cross-cultural and dialectic analysis of homes. In L. S. Liben, A. H. Patterson, \& N. Newcombe (Eds.), Spatial representation and behavior across the lifespan (pp. 283-320). New York: Academic Press.

Altman, I., \& Low, S. M. (1992). Place attachment. New York: Plenum Press.

Anthony, K. H. (1984). Moving experiences: memories of favorite homes. In D. Duerk, \& D. Campbell (Eds.), The challenge of diversity. Proceedings of the environmental design research association conference. San Luis Obispo, CA (pp. 141-149). Washington, DC: EDRA.

Brown, B. B. (1987). Territoriality. In D. Stokols, \& I. Altman (Eds.), Handbook of environmental psychology (pp. 505-531). New York: Wiley.

Brown, B., Perkins, D., \& Brown, G. (2003). Place attachment in a revitalizing neighborhood: individual and block levels of analysis. Journal of Environmental Psychology, 23, 259-271.

Brown, B. B., \& Perkins, D. D. (1992). Disruptions in place attachment. In I. Altman, \& S. M. Low (Eds.), Place attachment (pp. 279-304). New York: Plenum Press.

Brown, B., \& Werner, C. (1985). Social cohesiveness, territoriality, and holiday decorations: the influence of cul-de-sacs. Environment and Behaviour, 17, 539-565.

Denzing, N. K., \& Lincoln, Y. S. (1994). Handbook of qualitative research. Thousand Oaks, CA: Sage Publications, Inc.

Erikson, K. (1976). Everything in its path: Destruction of community in the buffalo creek flood. New York: Simon and Schuster.

Fried, M. (1963). Grieving for a lost home. In L. J. Duhl (Ed.), The urban condition (pp. 151-171). New York, USA: Basic Books.

Fromm, E. (1976). To have or to be? New York: Harper \& Row.

Gauvain, M., Altman, I., \& Fahim, H. (1983). Homes and social change: a crosscultural analysis. In N. R. Feimer, \& E. S. Geller (Eds.), Environmental psychology: Directions and perspectives (pp. 80-118). New York: Praeger.

Gerson, K., Stueve, C. A., \& Fischer, C. S. (1977). Attachment to place. In C. S. Fischer, R. M. Jackson, C. A. Stueve, K. Gerson, L. Jones, \& M. Baldassare (Eds.), Networks and places (pp. 139-161). New York: The Free Press.

Giuliani, M. V. (1991). Towards an analysis of mental representations of attachment to the home. Journal of Architecture and Planning Research 133-146.

Giuliani, M. V. (2003). Theory of attachment and place attachment. In M. Bonnes, T. Lee, \& M. Bonaiuto (Eds.), Psychological theories for environmental issues (pp. 137-170). England: Ashgate Publishing Limited.

Giuliani, M. V., \& Feldman, R. (1993). Place attachment in a developmental and cultural context. Journal of Environmental Psychology, 13, 267-274.

Hay, B. (1998). Sense of place in developmental context. Journal of Environmental Psychology, 18, 5-29.

Hernández, B., Hidalgo, M. C., Salazar-Laplace, M. E., \& Hess, S. (2007). Place attachment and place identity in natives and non-natives. Journal of Environmental Psychology, 27, 310-319.

Hidalgo, M. C., \& Hernández, B. (2001). Place attachment: conceptual and empirical questions. Journal of Environmental Psychology, 21, 273-281.

Ittelson, W. H. (1960). Visual space perception. New York: Springer.

Jörgensen, B. S., \& Stedman, R. C. (2001). Sense of place as an attitude: lakeshore owners attitudes toward their properties. Journal of Environmental Psychology, $21,233-248$.

Keshishian, K. (1972). 14th Romantic Cyprus (everybody's guide with illustrations and maps). Nicosia.

Keshishian, K. (1985). Famagusta town and district-Cyprus. Limassol: Famagusta Chamber of Commerce \& Industry.

Kitchin, R. M. (1994). Cognitive maps: what are they and why study them? Journal of Environmental Psychology, 14, 1-19.

Knez, I. (2005). Attachment and identity as related to a place and its perceived climate. Journal of Environmental Psychology, 25, 207-218.

Loizou, L. P. (1954). Louis tourist guide. Nicosia/Cyprus.

Manzo, L. C. (2003). Beyond house and haven: toward a revisioning of emotional relationships with places. Journal of Environmental Psychology, 23, 47-61.

Matter, D. E., \& Matter, R. M. (1988). Helping young children cope with the stress of relocation: action steps for the counsellor. Elementary School Guidance and Counselling, 23(1), 23-29.

Milligan, M. J. (1998). Interactional past and potential: the social construction of place attachment. Symbolic Interaction, 21, 1-33.

Moore, J. (2000). Placing home in context. Journal of Environmental Psychology, 20 , 207-218.

Necati, E. (1984). The Cyprus dispute and the birth of the Turkish Republic of Northern Cyprus. Nicosia: K. Rüsem and Brother. pp. 39-42.

Oliver-Smith. (1986). The martyred city: Death and rebirth in the Andes. Albuquerque: University of New Mexico Press.

Piaget, J., \& Inhelder, B. (1956). The child's conception of space. New York: Norton.

Proshansky, H. M. (1978). The city and self-identity. Environment and Behavior, 10 147-169.

Proshansky, H. M., Fabian, A. K., \& Kaminoff, R. (1983). Place identity: physical world socialization of the self. Journal of Environmental Psychology, 3, 57-83.

Quarantelli, E. L. (1957). The behavior of panic participants. Sociology and Social Research, 41

Raphale, B. (1986). When disasters strikes. New York: Basic Books, Inc.

Rowles, G. D. (1983). Place and personal identity in old age: observation from Appalachia. Journal of Environmental Psychology, 3, 299-313.

Sarbin, T. R. (1983). Place identity as a component of self: an addendum. Journal of Environmental Psychology, 3, 337-342. 
Schward, B., Brenth, R., Philips, R., \& Danley, M. (1995). Disruptions in place attachment following the 1993 big flood. In J. L. Nasar, P. Grannis, \& K. Hanyu (Eds.), Twenty sixth annual conference. Proceedings of the of the environment design research association conference (pp. 92-98). Massachusetts: EDRA.

Stedman, R.C.(2002). Toward social psychology of place. Predicting behavior from placebased cognitions, attitude, and identity. Environment and Behavior, 34, 561-581.

Stewart, W. P., Liebert, D., \& Larkin, K. W. (2004). Community identities as visions for landscape change. Landscape and Urban Planning, 69, 315-334.

Taylor, R. B., Gottfredson, S. D., \& Brower, S. (1984). Block crime and fear: defensible space, local social ties, and territorial functioning. Journal of Research in Crime and Delinquency, 21, 303-331.
Tuan, Y. (1974). Topophilia. Englewood Cliffs, NJ: Prentice-Hall, Inc.

Twigger-Ross, C. L., \& Uzzell, D. L. (1996). Place and identity processes. Journal of Environmental Psychology, 16, 205-220.

Vorkinn, M., \& Riese, H. (2001). Environmental concern in a local context: the significance of place attachment. Environment and Behavior, 33, 249-263.

Williams, D. R., \& Vaske, J. J. (2003). The measurement of place attachment: validity and generalizability of a psychometric approach. Forest Science, 49, 830-840.

Winkel, G. (1981). The perception of neighbourhood change. In J. Jarvey (Ed.) Cognition and social behaviour and the environment. New York: Erlbaum.

Wright, J. D., \& Rossi, P. H. (1981). Social science and natural hazards. Cambridge, MA: Abt Books. 